\title{
ANALYSIS OF ENTERTAINMENT TAX CONTRIBUTION TO THE ORIGINAL REVENUE OF MANADO CITY
}

\author{
Selvie J. Nangoi, Antonius A. Tandi \\ Department of Accounting, Polytechnic of Manado Country \\ DOI: 10.31364/SCIRJ/v7.i12.2019.P1219732 \\ http://dx.doi.org/10.31364/SCIRJ/v7.i12.2019.P1219732
}

\begin{abstract}
Tax entertainment in the city of Manado has an important role for Regional Original Revenues, including regional development, job creation, as well as exploring sources of regional income. Therefore, each region is required to raise awareness for entertainment taxpayers, for their responsibilities in regional development. The purpose of this study was to determine the contribution of entertainment tax to local taxes, and the contribution of entertainment tax to, and the impact of entertainment tax on the city of Manado. The research method used is a qualitative descriptive analysis of the condition of natural objects, namely the reception of Local Original Revenue. The data used are observation, interview, and documentation. Resource persons from this study are the State Civil Apparatus, Regional Revenue Agency. The results showed that the Manado City Entertainment Tax revenue for four years, namely 2014 - 2017 experienced a change from an increase to a decrease in each year. There is a government effort through monitoring to optimize entertainment tax revenue. Hopefully, the government should conduct an examination in each district that has potential as a source of local tax revenue.
\end{abstract}

Keywords: Analysis of Entertainment Tax Contributions

\section{INTRODUCTION}

The people of Manado City have realized that the potential of tourism originating from the natural, social and cultural environment has a very strong driving force, to boost the economic development sector. To achieve this, the government and all elements of society work together in maintaining and enhancing the value of their charms; the efforts made include tourism facilities and infrastructure that are improved, and more attention; performance of art and dance; cultural exhibition typical of the city of Manado; Folk / traditional arts entertainment; heritage of ancestral personalities; rare and unique customs or traditions, or other interesting things. With this diversity of tourism potentials, it is hoped that the city of Manado can contribute in driving the economic activities of the community, expanding and leveling employment and business opportunities, increasing income and welfare of the community, optimally supporting the acquisition of local revenue. Based on data obtained by the Regional Revenue Agency regarding taxpayers in Manado from 2014 - 2017 as follows:

Table 1.1

Entertainment Taxpayers for 2014 - 2017

\begin{tabular}{|c|c|}
\hline Year & Amount \\
\hline 2014 & 85 \\
\hline 2015 & 131 \\
\hline 2016 & 155 \\
\hline 2017 & 114 \\
\hline
\end{tabular}

Source: Regional Revenue Agency, 2019

Based on 2014 it only had 85 taxpayers, and there was an increase in 2015 of 131 taxpayers, so that it had an increase of 46, then in 2016 it had a significant increase compared to 2015 of 155, so that it had an increase of 24, and in in 2017 there was a decrease in taxpayers by 114 with a comparison of 41 . Thus, from sources there is the year 2016 which has the largest increase in the period of research. To see the data of entertainment taxpayers from 2014 - 2017 can be seen in the table. Therefore, the regional 
government can try to increase revenue from the region itself, so that it will increase the availability of regional finances, which can be used to finance regional development.

Table 1.2

Regional Revenue (Entertainment Tax)

\begin{tabular}{|c|c|c|c|}
\hline Year & Target (IDR) & Realisasi (IDR) & Achieved (\%) \\
\hline 2014 & 7.349 .999 .850 & 7.280 .563 .807 & 99.06 \\
\hline 2015 & 9.000 .000 .000 & 9.039 .266 .285 & 100.04 \\
\hline 2016 & 10.000 .000 .000 & 11.012 .273 .849 & 110.12 \\
\hline 2017 & 11.500 .000 .000 & 11.556 .376 .025 & 100.49 \\
\hline Total & $\mathbf{3 7 . 8 4 9 . 9 9 9 . 8 5 0}$ & $\mathbf{3 8 . 8 8 8 . 4 7 9 . 9 6 6}$ & $\mathbf{4 0 0 , 7 1}$ \\
\hline
\end{tabular}

Source: Regional Revenue Agency, 2019

The cause of not achieving the target in the Entertainment Tax, due to lack of awareness of the Entertainment Taxpayer in calling himself to give responsibility in regional development. Then the local government, seeks to increase Regional Original Revenue. Then the local government, seeks to increase Regional Original Revenue. This needs to be considered, because of the importance of taxes for local governments, and is a very crucial factor for an area to develop its own region. Therefore, the Manado city government each year seeks to improve governance so that it is better, the effort is in the form of increasing local taxes through intensification and extensification, as well as exploring sources of regional revenue, especially revenue from the region itself. Based on the background above, the researcher is interested in conducting research by taking the title of research on "Analysis of the Contribution of Entertainment Taxes to the Original Revenue of the City of Manado".

\section{RESEARCH METHODS}

The research method used is qualitative descriptive method.

\subsection{Data source}

1. Primary Data, i.e. data obtained through direct observation or interviews of Regional Revenue Agency employees, namely:

a. Realization of Manado City entertainment tax from $2014-2017$

b. Realization of Regional Revenue of Manado City from 2014-2017

2. Secondary data is a complement of the data obtained in a ready-made form. In addition to information held by the company, researchers obtained information from books and related internet sites, which is a general description of the City of Manado.

\subsection{Data collection technique}

In this research, the data collection methods used were observation, interviews, and documentation.

1. Observation

Observation is one data collection technique that has a purpose, to add information needed in research. Observation has the advantage, that researchers can see the situation, the actual work processes occurring at the Regional Revenue Agency.

2. Interview

Interview is a data collection technique that is carried out with a question and answer session that is carried out systematically, planned, and refers to the research objectives.

The purpose of the interview is to find out:

1) A general description of the company.

2) Accounting Information System used by the company.

3) Documents and Notes used.

4) Inventory management procedures, consumables

3. Documentation

Documentation is a data collection technique by analyzing documents created by the Regional Revenue Agency. Documentation is used to obtain information about receipts, expenses and cash management of the company, and an overview of the company's activities. 


\subsection{Data analysis technique}

The data analysis technique used in this research is a qualitative descriptive analysis. According to Sugiyono (2010), "Qualitative descriptive is a research method used to examine natural object conditions and not experiments, with data analysis that is inductive / qualitative, and the results of research emphasize more on meaning than generalization", in other words analysis Descriptive qualitative research is aimed at defining a situation, or phenomenon as it is. This analysis provides a systematic and accurate picture of the data obtained. This data analysis technique is used to answer the problem formulation, at the Regional Revenue Agency. The data analysis process is an attempt to obtain answers to research problems are:

1. Data collection

a. Obtaining the amount of entertainment tax realization in 2014 - 2017. Entertainment tax realization data, obtained from the report on the realization of entertainment tax revenue in the Regional Revenue Agency.

b. Obtaining the amount of realization of regional own-source revenue in 2014-2017. Realization data of regional ownsource revenue, obtained from the report on the realization of regional own-source revenue, which is in the Regional Original Revenue Agency

2. Data analysis

a. To answer the first problem, how much is the contribution of Entertainment Tax to Regional Taxes in Manado City in 2014 - 2017 carried out with the formula:

$$
\frac{\text { Entertainment Tax Receipts }}{\text { Regional Original Tax Receipts }} 100 \%
$$

b. To answer the second question, how much is the contribution of Entertainment Tax to the Regional Original Tax and its impact using the formula:

$$
\frac{\text { Entertainment Tax Receipts }}{\text { Regional Original Tax Receipts }} 100 \%
$$

c. To answer the third question how effective is the Entertainment Tax using the formula:

$$
\begin{aligned}
& \frac{\text { Realization of entertainment tax revenue }}{\text { Entertainment tax revenue target }} \\
& \text { III. DISCUSSION }
\end{aligned}
$$

\section{A. Effectiveness of Entertainment Tax Contribution to Original City Revenue of Manado City in 2014-2017.}

Research and analysis of this data is used to find out how much the contribution of Entertainment Taxes to the Regional Original Income, namely by comparing the reception of Entertainment Taxes, and receipts of Local Original Revenues, and transferred $100 \%$. Meanwhile, to find out the effectiveness level of Entertainment Tax against Regional Original Tax, namely by comparing the realization of entertainment tax revenue with the target of Entertainment Tax revenue, as well as Regional orginal Revenue and transferred $100 \%$. The calculation of the percentage of contributions, the percentage of contributions, and the percentage of effectiveness of the Entertainment Tax on Regional Orginal Revenue in the City of Manado, starting in the 2014-2017 fiscal year is as follows:

a. Contribution of Entertainment Taxes to Regional Original Taxes

$$
\frac{\text { Entertainment Tax Receipts }}{\text { Regional Original Tax Receipts }} 100 \%
$$

Table 3.1

Contribution of Entertainment Taxes for Manado City Original Taxes 2014-2017

\begin{tabular}{|c|c|c|c|}
\hline Year & $\begin{array}{c}\text { Realization of Entertainment Tax } \\
\text { Revenue (IDR) }\end{array}$ & Regional Original Tax Receipts (IDR) & $\begin{array}{c}\text { Contribution } \\
(\%)\end{array}$ \\
\hline 2014 & 7.280 .563 .807 & 263.392 .296 .958 & 0,27 \\
\hline 2015 & 9.039 .266 .285 & 289.462 .741 .463 & 0,31 \\
\hline 2016 & 11.012 .273 .849 & 306.453 .382 .648 & 0,35 \\
\hline
\end{tabular}

www.scirj.org

(C) 2019, Scientific Research Journal

http://dx.doi.org/10.31364/SCIRJ/v7.i12.2019.P1219732 


\begin{tabular}{|l|l|l|l|}
\hline 2017 & 11.556 .376 .025 & 404.022 .975 .915 & 0,28 \\
\hline
\end{tabular}

Source: Processed Data, 2019

The calculation results presented in table 3.1 show that the contribution of Entertainment Taxes to the Original Tax Daearh in 2014 to 2017 ranged from $0.27 \%-0.35 \%$. In 2017 the Entertainment Tax has increased in its realization, but the contribution made has decreased, or smaller than the previous year. This is because the realization of the Entertainment Tax was also followed by an increase in Regional Original Revenues. From the contribution given in 2016 of $0.35 \%$, in 2017 it dropped to $0.28 \%$, or decreased by $0.07 \%$ from the previous year. The average contribution given by the Entertainment Tax to Regional Original Revenues, during 2014 to 2017 was $0.30 \%$. Whereas the biggest contribution of Entertainment Tax to Regional Original Income occurred in 2016 with a contribution of $0.35 \%$, and the smallest contribution occurred in 2014 with a contribution of $0.27 \%$.

b. Effectiveness:

\section{$\frac{\text { Realization of entertainment tax revenue }}{\text { Target entertainment tax revenue }} 100 \%$}

Table 3.2

Effectiveness of Manado City Entertainment Taxes 2014 to 2017

\begin{tabular}{|c|c|c|c|}
\hline Year & $\begin{array}{c}\text { Realization of Entertainment } \\
\text { Tax revenue (IDR) }\end{array}$ & Target Entertainment Tax Revenue (IDR) & Effectiveness (\%) \\
\hline 2014 & 7.280 .563 .807 & 7.349 .999 .850 & 99,05 \\
\hline 2015 & 9.039 .266 .285 & 9.000 .000 .000 & 100,43 \\
\hline 2016 & 11.012 .273 .849 & 10.000 .000 .000 & 110,12 \\
\hline 2017 & 11.556 .376 .025 & 11.500 .000 .000 & 100,49 \\
\hline
\end{tabular}

Source: Processed Data, 2019

The calculation results presented in table 3.2 show that the effectiveness of the 2014 Entertainment Tax up to 2017 ranged from $99.05 \%-110.12 \%$. In 2016 there was an increase in its realization, but the effectiveness provided has decreased, or smaller than the previous year. This is due to the realization of the Entertainment Tax also followed by an increase in the Entertainment Tax revenue target. From contributions made in 2016 amounting to $110.12 \%$, then in 2017 it dropped to $100.49 \%$, or reduced by $9.63 \%$ from the previous year. The average effectiveness provided by the Entertainment Tax during 2014-2017 was 102.52\%. While the effectiveness of the largest Entertainment Tax occurred in 2016 with an effectiveness of $110.12 \%$, and the smallest contribution occurred in 2014 with an effectiveness of 99.05\%. Which means that the effectiveness of Entertainment Tax during 2014 to 2017 in the previous year, namely in 2014 the realization of the Entertainment Tax, did not reach the target in the realization of the Entertainment Tax.

\section{B. Contribution of Entertainment Tax Objects to Regional Original Revenue}

Table. 3.3

Contribution from Entertainment Tax Objects, 2014

\begin{tabular}{|c|c|c|c|}
\hline \multirow{2}{*}{ Information } & Objects and Entertainment Tax Rates & $\begin{array}{c}\text { Receipt of Each Entertainment } \\
\text { Tax Object (IDR) }\end{array}$ & Contribution \\
\hline A & Discos, karaoke, night clubs, bars and the like 35\% & 888.228 .784 & $12,20 \%$ \\
\hline B & Agility game, 30\% & 738.249 .170 & $10,14 \%$ \\
\hline C & Massage parlor, reflexology, steam bath / spa 20\% & 766.643 .369 & $10,53 \%$ \\
\hline D & Fitness center 20\% & 766.643 .369 & $10,53 \%$ \\
\hline E & Playing golf, billyard and bowling 25\% & 582.445 .105 & $8,00 \%$ \\
\hline F & Art and dance performances 10\% & - \\
\hline G & Bodybuilding and the like 25\% & 582.445 .105 & $8,00 \%$ \\
\hline H & Exhibitions (except those carried out by government & 728.056 .381 & $10,00 \%$ \\
\hline I & Circusencies) 30\% acrobat and magic, 30\% & 728.056 .381 & $10,00 \%$ \\
\hline J & Horse racing, motorized vehicles, 30\% & 728.056 .381 & $10,00 \%$ \\
\hline K & Sports match, 10\% & 43.683 .383 & $0,60 \%$ \\
\hline L & Fashion show, beauty pageant, 30\% & $\mathbf{7 2 8 . 0 5 6 . 3 8 1}$ & - \\
\hline M & Folk arts entertainment / traditional 10\% & - & $-00 \%$ \\
\hline & Total & $\mathbf{7 . 2 8 0 . 5 6 3 . 8 0 7}$ & \\
\hline
\end{tabular}

Source: Processed Data, 2019

www.scirj.org

(C) 2019, Scientific Research Journal

http://dx.doi.org/10.31364/SCIRJ/v7.i12.2019.P1219732 
In 2014 the contribution of entertainment tax to local revenue, from each of the existing entertainment tax objects, contributed in accordance with the discounted rate that has been determined.

Table 3.4

Contribution from Entertainment Tax Objects, 2015

\begin{tabular}{|c|c|c|c|}
\hline Information & Objects and Entertainment Tax Rates & $\begin{array}{l}\text { Receipt of Each Entertainment } \\
\text { Tax Object (IDR) }\end{array}$ & Contribution \\
\hline A & $\begin{array}{l}\text { Discos, karaoke, night clubs, bars and the like } \\
\qquad 35 \%\end{array}$ & 1.355 .889 .943 & $15,00 \%$ \\
\hline $\mathrm{B}$ & Agility game, $30 \%$ & 903.926 .629 & $10,00 \%$ \\
\hline $\mathrm{C}$ & $\begin{array}{l}\text { Massage parlor, reflexology, steam bath / spa } \\
20 \%\end{array}$ & 705.062 .770 & $7,80 \%$ \\
\hline $\mathrm{D}$ & Fitness center $20 \%$ & 741.219 .835 & $8,20 \%$ \\
\hline $\mathrm{E}$ & Playing golf, billyard and bowling $25 \%$ & 813.533 .966 & $9,00 \%$ \\
\hline $\mathrm{F}$ & Art and dance performances $10 \%$ & - & - \\
\hline $\mathrm{G}$ & Bodybuilding and the like $25 \%$ & 451.963 .314 & $5,00 \%$ \\
\hline $\mathrm{H}$ & $\begin{array}{c}\text { Exhibitions (except those carried out by } \\
\text { government agencies) } 30 \%\end{array}$ & 903.926 .629 & $10,00 \%$ \\
\hline I & Circus, acrobat and magic, $30 \%$ & 903.926 .629 & $10,00 \%$ \\
\hline $\mathrm{J}$ & Horse racing, motorized vehicles, $30 \%$ & 903.926 .629 & $10,00 \%$ \\
\hline $\mathrm{K}$ & Sports match, $10 \%$ & 451.963 .314 & $5,00 \%$ \\
\hline $\mathrm{L}$ & Fashion show, beauty contest $30 \%$ & 903.926 .629 & $10,00 \%$ \\
\hline M & Folk arts entertainment / traditional $10 \%$ & - & - \\
\hline & Total & 9.039.266.285 & \\
\hline
\end{tabular}

Source: Regional Revenue Agency, 2019

The contribution of entertainment tax in 2015 according to the discounted tax rate of each entertainment object showed an increase from the previous year, the total contribution of each tax object in 2014 was IDR 7,280,563,807, then in 2015 it rose to IDR. $9,039,266,285$.

Table 3.5

Contribution from Entertainment Tax Objects, 2016

\begin{tabular}{|c|c|c|c|}
\hline Information & Objects and Entertainment Tax Rates & $\begin{array}{c}\text { Receipt of Each } \\
\text { Entertainment Tax Object } \\
\text { (IDR) }\end{array}$ & Contribution \\
\hline A & $\begin{array}{c}\text { Discos, karaoke, night clubs, bars and the } \\
\text { like 35\% }\end{array}$ & 1.651 .841 .077 & $15,00 \%$ \\
\hline B & Agility game, 30\% & 1.101 .227 .385 & $10,00 \%$ \\
\hline C & Massage parlor, reflexology, steam bath / & 880.981 .908 & $8,00 \%$ \\
\hline s & Fitness center 20\% & 880.981 .908 & $9,00 \%$ \\
\hline E & Playing golf, billyard and bowling 25\% & 991.104 .646 & $9,00 \%$ \\
\hline F & Art performance and dance 10\% & & $10,00 \%$ \\
\hline H & Bodybuilding and the like 25\% & 991.104 .646 & 1.101 .227 .385 \\
\hline
\end{tabular}




\begin{tabular}{|c|c|c|c|}
\hline I & Circus, acrobat and magic, 30\% & 1.101 .227 .385 & $10,00 \%$ \\
\hline J & Horse racing, motorized vehicles, 30\% & 1.101 .227 .385 & $10,00 \%$ \\
\hline K & Sports match, 10\% & 220.245 .477 & $2,00 \%$ \\
\hline L & Fashion show, beauty contest 30\% & 991.104 .646 & - \\
\hline M & Folk arts entertainment / traditional 10\% & - & - \\
\hline
\end{tabular}

Source: Regional Revenue Agency, 2019

The contribution of entertainment tax in 2016 again increased by IDR. 1,973,007,564 from the previous year, so that it has a positive impact on income, and regional development through the object of entertainment tax.

Table. 3.6

Contribution from Entertainment Tax Objects, 2017

\begin{tabular}{|c|c|c|c|}
\hline \multirow{2}{*}{ Information } & Objects and Entertainment Tax Rates & $\begin{array}{c}\text { Objects and Entertainment Tax } \\
\text { Rates (IDR) }\end{array}$ & Contribution \\
\hline A & $\begin{array}{c}\text { Discos, karaoke, night clubs, bars and the like } \\
35 \%\end{array}$ & 1.733 .456 .404 & $15,00 \%$ \\
\hline B & Agility game, 30\% & 1.155 .637 .603 & $10,00 \%$ \\
\hline C & Massage parlor, reflexology, steam bath / spa & 1.040 .073 .842 & $9,00 \%$ \\
\hline D & Fitness center 20\% & 1.040 .073 .842 & $9,00 \%$ \\
\hline E & Playing golf, billyard and bowling 25\% & 577.818 .801 & $5,00 \%$ \\
\hline F & Art performance and dance 10\% & - & $9,00 \%$ \\
\hline H & Bodybuilding and the like 25\% & 1.040 .073 .842 & $10,00 \%$ \\
\hline I & Exhibitions (except those carried out by & 1.155 .637 .603 & $10,00 \%$ \\
\hline government agencies) 30\% & Circus, acrobat and magic, 30\% & 1.155 .637 .603 & $10,00 \%$ \\
\hline K & Horse racing, motorized vehicles, 30\% & 1.155 .637 .603 & - \\
\hline L & Fashion show, beauty contest 30\% & 1.155 .637 .603 & $10,00 \%$ \\
\hline M & Folk arts entertainment / traditional 10\% & 346.691 .281 & $3,00 \%$ \\
\hline & Total & $\mathbf{1 1 . 5 5 6 . 3 7 6 . 0 2 5}$ & \\
\hline
\end{tabular}

Source: Regional Revenue Agency, 2019

In 2017 the entertainment tax has increased again in its contribution to local own-source revenue, seen from the total revenue of IDR. 11,556,376,025, although in the object of sports competition tax, and artistic performances do not contribute in 2017.

\section{Analysis of the Contribution of Entertainment Taxes to Regional Orginal Revenue}

Table 3.1 results show that the contribution of the Entertainment Tax to the Original Revenue of the City of Manado has Enough criteria. It can be seen from 2014 that the presentation of Entertainment Tax contribution in the city of Manado was only 0.27\%. In 2015 and 2016 the contribution of Entertainment Tax towards Local Taxes in the City of Manado increased, although the increase was not too large. Then, the contribution of Entertainment Tax towards Regional Original Revenues in Manado City decreased in 2017 by $0.28 \%$. So the average contribution of Local Taxes to Regional Original Revenue in Manado City is $0.30 \%$. To answer the first question, how much is the contribution of the Entertainment Tax to the Regional Orginal Revenues using the following criteria:

Table 3.7

Criteria for the value of the contribution of Entertainment Tax to Regional Orginal Revenue

\begin{tabular}{|c|c|}
\hline Percentage of contributions & Criteria \\
\hline $0-10 \%$ & Very Less \\
\hline
\end{tabular}




\begin{tabular}{|c|c|}
\hline $10,10 \%-20 \%$ & Less \\
\hline $20,20 \%-30 \%$ & Enough \\
\hline $30,10 \%-40 \%$ & Between Enough and Well \\
\hline $40,10 \%-50 \%$ & Well \\
\hline $50 \%$ & Very Well \\
\hline
\end{tabular}

Source : TimLitbang Perdagri Fisipol UGM, 1991

Impact on Regional Original Revenue, namely the higher the Regional Tax revenue, especially Entertainment Tax, the Regional Genuine Tax revenue will increase. And conversely, if the contribution of the Entertainment Tax is very low then the reception of the Regional Original Tax will decrease. This has an impact on regional development, because the Regional Tax is the regional income used to develop the region, such as rural development, increased investment, creating job opportunities, improving quality, equitable implementation of education and health

\section{Effectiveness of Entertainment Taxes on Regional Original Revenues}

Table 3.2 shows that Entertainment Tax revenue in the city of Manado for the target in 2014 was IDR 7,349,999,850, while the realization was IDR. 7,280,563,807. So that if it is made in accordance with the above calculation method, it will get a realization of 99.05\%. In 2015 there was an increase in the target for IDR Entertainment Tax IDR 9,000,000,000. Entertainment Tax Revenues in 2015 and 2016 have increased, in the realization of the fact that there is an Entertainment Tax revenue of IDR. 9,039,266,285 and IDR. $11,012,273,849$, then an increase in percentage, namely $100.43 \%$ and $110.12 \%$. This is also due to an increase in the Manado City Entertainment Tax revenue target. To answer the second question, namely how much effectiveness the Entertainment Tax has on the Local Revenue using the criteria:

Table 3.8

Entertainment Tax Effectiveness Criteria

\begin{tabular}{|c|c|}
\hline Percentage of contributions & Criteria \\
\hline Above $100 \%$ & Very Effective \\
\hline $90 \%-100 \%$ & Effective \\
\hline $80 \%-90 \%$ & Effective Enough \\
\hline $60 \%-80 \%$ & Less Effective \\
\hline Less than $60 \%$ & Ineffective \\
\hline
\end{tabular}

Source : Tim Litbang Perdagri Fisipol UGM, 1991

In 2017 the effectiveness of entertainment tax revenue from Regional Original Income in Manado City decreased by $9.63 \%$. In this case, by looking at the target, and realization of Entertainment Tax revenue, the average Entertainment Tax revenue in 2014 to 2017 was $114.68 \%$. When viewed from the effectiveness of Entertainment Tax revenue in the city of Manado, it has not been fully effective because of the increase and decrease. In the realization of entertainment tax, it has not yet fully contributed in developing the region. Therefore, a bigger target is needed, to increase Regional Original Revenues in the City of Manado. Components that have the greatest influence on Entertainment Taxes, namely the actors as well as managers of the Entertainment Tax source itself, many Entertainment places that have not been registered with Entertainment Taxpayers, for example karaoke rooms, spas and other massage parlors, have not reported and paid Entertainment Taxes. This is an obstacle faced by the Manado City Revenue Agency in collecting Entertainment Taxes. Efforts made by the government, namely by increasing supervision carried out by jumping officers from the Regional Revenue Agency to the field, to submit tax returns and do a cross check, regarding the truth of the submission and calculation of tax debt. In addition, the government must continue to strive to increase and explore the potential of sources of funding from the Entertainment Tax, which can increase the contribution of the Entertainment Tax to Manado's Original Local Revenue.

\section{Conclusion}

From the discussion that has been described above can be concluded as follows: 
1. In its realization report, Manado City Entertainment Tax revenue for four years from 2014 to 2017 has changed from an increase to a decrease in each year. It can be seen that the receipt of the Entertainment Tax against the Original Local Tax in the City of Manado in 2017 the Entertainment Tax has increased in its realization. This is caused due to the realization of the Entertainment Tax, followed by an increase in local revenue. From contributions made in 2016 of $0.35 \%$, in 2017 it dropped to $0.28 \%$ or decreased by $0.07 \%$ from the previous year.

2. According to its effectiveness, the Entertainment Tax in Manado is quite effective because the realization of the Entertainment Tax has increased, although in early 2014 the realization of the Entertainment Tax revenue did not reach the Entertainment Tax revenue target. Because of the lack of awareness of the Entertainment Taxpayers in calling themselves to give responsibilities in regional development

3. There are several efforts by the government or the Regional Revenue Agency through monitoring to optimize the reception of Entertainment Taxes in the City of Manado, namely the identification of the collection of Entertainment Taxes, Extending the sources of Entertainment Taxes, the addition of the number of employees in the Regional Revenue Agencies, improving services to the community in the form of additional locations for counters taxes in the city administration area, organizing socialization of Regional Taxes, and improving management of complaints handling regarding Regional Taxes. After conducting research, researchers try to provide input and suggestions. If it can be useful for the Manado City Regional Revenue Agency, the input and suggestions that the author can give are:

a. The government should conduct an examination in each sub-district, which has the potential as a source of regional tax revenue. But not necessarily already registered or registered as a taxpayer, and evaluating in every sub-district that has been recorded, or registered as a taxpayer.

b. The Manado City Regional Revenue Agency tax service office is encouraged to improve the quality of administration and operations in a professional and optimal manner. With hope, provide faster service, and of course maintain friendliness for taxpayers.

\section{REFERENCES}

Lamia, Alfan. 2015. Analisis Efektivitas Dan Kontribusi Pemungutan Pajak Restoran, Pajak Reklame, Dan Pajak Penerangan Jalan Pada Pendapatan Asli Daerah Kabupaten Minahasa Utara. https://ejournal.unsrat.ac.id/index.php/jbie/article/view/10474

Lengkong, Vanessa Angela. 2016. Analisis Efektivitas Realisasi Pajak Hotel Dan Kontribusinya Terhadap Pendapatan Asli Daerah Pada Dinas Pendapatan Daerah Kota Bitung. https://ejournal.unsrat.ac.id/index.php/jbie/article/view/13585

Mahmudi. 2019. Analysis of Regional Government Financial Statements, Yogyakarta : Sekolah Tinggi Ilmu Manajemen YKPN.

Mardiasmo. 2016. Taxation. Yogyakarta : Andi.

Melinda, Cahaya, 2017, Analisis Kontribusi Pajak Hiburan Terhadap Pendapatan Asli Daerah (PAD). Jurusan Akuntansi, Fakultas Ekonomi, Universitas Sanata Dharma Yogyakarta

Siahaan, Marihot Pahala. Regional Taxes and Regional Retribution. Jakarta : PT. Rajagrafindo Persada.

Sari Diana. 2013. Basic Concepts of Taxation. Bandung : PT. Refika Aditama.

Sugiyono. 2014. Quantitative, Qualitative Research Methods, and R\&D.. Bandung : Alfabeta.

Sugiyono, 2010, Metode Penelitian Pendidikan Pendekatan Kuantitatif, Kualitatif, dan R\%D, Bandung: Alfabeta

UUD No 16, 2009,Tentang Ketentuan Umum Tata Cara Perpajakan

www.scirj.org

(C) 2019, Scientific Research Journal

http://dx.doi.org/10.31364/SCIRJ/v7.i12.2019.P1219732 